Original Article

\title{
Optimization of parameters for obtaining callus, suspension, and root cultures of meadowsweet (filipendula ulmaria) to isolate the largest number of biologically active substances with geroprotective properties
}

\author{
Otimização de parâmetros para obtenção de culturas de calos, suspensão e raiz \\ de Ulmária (Filipendula ulmaria) para isolar o maior número de substâncias \\ biologicamente ativas com propriedades geroprotetoras
}

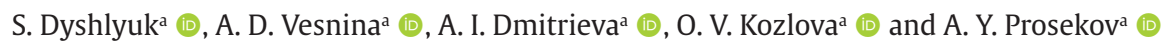

aKemerovo State University, Kemerovo, Russia

\begin{abstract}
The study of biologically active substances-secondary metabolites of plants that exhibit geroprotective properties is an actual and popular direction in medicine to prevent early aging. This work aims to select the cultivation parameters for obtaining in vitro cell cultures of meadowsweet containing the largest amount of biologically active substances (BAS) for their further extraction as candidate substances for geroprotectors. To specify the effectiveness of the selected cell culture cultivation parameters, biomass growth for callus and root cultures, growth index, specific growth rate, and viability for suspension cultures was carried out. The study results made it possible to select the nutrient media for the cultivation of cell cultures of meadowsweet. It has been found that the greater the antioxidant activity of the extracts, the greater the antimicrobial properties it exhibits. In this study, cell cultures in vitro and alcohol extracts from the plant Filipendula ulmaria were considered as raw materials rich in candidate substances for geroprotectors. According to the data obtained, the plant is rich in hydroxybenzoic and salicylic acids, spireoside, avicularin, and hyperoside.
\end{abstract}

Keywords: biologically active substances, geroprotector, aging, meadowsweet, cell cultures in vitro, antimicrobial activity.

\section{Resumo}

O estudo de substâncias biologicamente ativas - metabólitos secundários de plantas que apresentam propriedades geroprotetoras - é uma tendência atual e popular no campo da medicina para a prevenção do envelhecimento precoce. $\mathrm{O}$ objetivo deste trabalho foi selecionar os parâmetros de cultivo para obtenção de culturas celulares in vitro de Ulmária contendo a maior quantidade de substâncias biologicamente ativas (SBA), para sua posterior extração como substâncias candidatas a serem geroprotetoras. Para especificar a eficácia dos parâmetros selecionados de cultivo em cultura de células, foi realizada a análise de crescimento de biomassa para culturas de calos e raízes, índice de crescimento, taxa de crescimento específica e viabilidade para culturas em suspensão. Os resultados do estudo possibilitaram a seleção do meio nutriente para o cultivo de células de Ulmária. Verificou-se que, quanto maior a atividade antioxidante dos extratos, maiores eram as propriedades antimicrobianas exibidas. Neste estudo, culturas celulares in vitro e extratos alcoólicos da planta Filipendula ulmaria foram considerados matérias-primas ricas em substâncias candidatas a serem geroprotetoras. De acordo com os dados obtidos, a planta é rica em ácidos hidroxibenzoico e salicílico, espirosídeo, avicularina e hiperosídeo.

Palavras-chave: substâncias biologicamente ativas, geroprotetor, envelhecimento, ulmária, cultura de células in vitro, atividade antimicrobiana.

\section{Introduction}

Aging is a complex process that influences all systems of the body (molecular, cellular, tissue, etc. (Ito et al., 2012; Moskalev et al., 2017). This process is accompanied by a number of chronic diseases (stroke, diabetes, cancer, neurodegenerative diseases, etc. (Liu et al., 2019; Tsai et al., 2021; Jansen et al., 2015), leading to a gradual decrease in physical and mental abilities. Geroprotectors are pharmacological substances that can slow down the 
processes associated with early aging and increase healthy life expectancy (Figueiredo et al., 2010; Proshkina et al., 2020; Tundisi et al., 2008). Not all biologically active compounds can be used as geroprotectors. The work of A. Moskalev and his colleagues presented a number of criteria that candidate substances should meet for geroprotectors (Moskalev et al., 2017):

1. The possibility of increasing the duration and quality of life.

2. The ability to maintain a young state of the body and suppress age-related changes.

3. The dose of the geroprotector used should not be toxic to the body.

The implementation of these criteria is possible due to the protection of the body from one or more aging mechanisms (Proshkina et al., 2020). One of the most popular theories of aging is the free radical or antioxidant theory (Harman, 2002, 2003), since free radicals are involved in the creation of cellular damage and in inflammatory processes (Pollack and Leeuwenburgh, 1999; Campisi et al., 2019). As a result, the search for BAS that exhibit antioxidant properties is relevant.

Plant raw materials are a popular source of candidate substances for geroprotectors (Lincheva et al., 2017; Asyakina et al., 2020; Koval et al., 2021). Most often, secondary plant metabolites - avonoids, polyphenols, glycosides, tannins, and vitamins-are used as geroprotectors
(Lashmanova et al., 2019). Thus, the elm-leaf meadowsweet or elm-leaf labaznik (Filipendula ulmaria) is a perennial herbaceous plant rich in phenolic compounds, tannins, polysaccharides, and essential oils, due to which it exhibits a high spectrum of pharmacological activity (antioxidant activity, immunomodulatory properties, etc.) (Olennikov et al., 2016; Baranenko et al., 2019; Dyshlyuk et al., 2021; Piwowarski et al., 2014).

To overcome the difficulties that arise in the traditional reproduction of plants, it is important to use biotechnological methods that allow obtaining pure biomaterial on a large scale and contribute to the conservation of plant species diversity (Cristiano et al., 2016; Yong et al., 2020).

This work aims to select the optimal parameters for the production of callus, suspension, and root cultures of meadowsweet (Filipendula ulmaria) to extract the maximum amount of BAS showing geroprotective activity. The algorithm for implementing this work is shown in Figure 1.

[Figure 1]

\section{Methodology}

The paper aims to evaluate the biomass of callus, suspension, and root cultures in vitro of meadowsweet

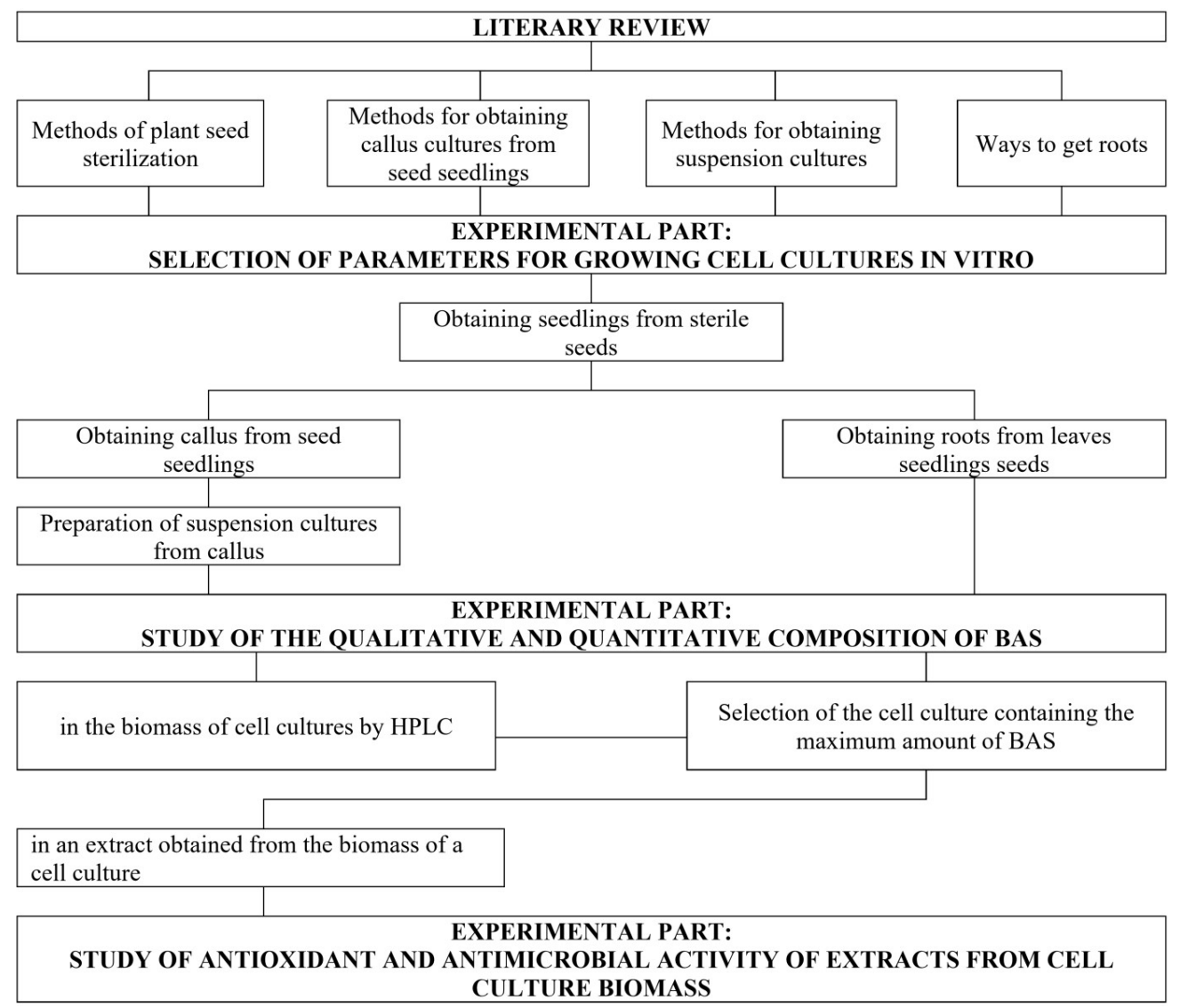

Figure 1. The algorithm of the study in this paper. 
(Filipendula ulmaria) and water-alcohol extracts obtained from the biomass of these cultures.

- Production of callus and root cultures in vitro was carried out from the seeds of meadowsweet (the seeds were purchased from the private collection of Sirotkin E. K., Russia). The method of seed sterilization included the following steps: the seeds were sterilized in $5 \mathrm{ml}$ of a solution (3\% hydrogen peroxide and $96 \%$ ethanol in a ratio of $1: 1$ ) for 2 minutes, then dried in a stream of sterile air on a sterile filter paper. After sterilization, the seeds were planted on an agarized medium (the composition of the medium is shown in Table 1 ). [Table 1]

- For the induction of callus cell cultures, 2-8-week-old sterile seedlings with 2-4 real leaves were used. The stems and leaves were cut into pieces and planted on agarized media in Petri dishes with 60 and $90 \mathrm{~mm}$

Table 1. Composition of the nutrient medium for obtaining sterile seedlings from the seeds of meadowsweet.

\begin{tabular}{cc}
\hline $\begin{array}{c}\text { Components of the } \\
\text { nutrient medium }\end{array}$ & $\begin{array}{c}\text { Quantity per 1 liter of } \\
\text { distilled water }\end{array}$ \\
\hline Macrosols 20x MS, ml & 50.00 \\
Microsols 20x SH, ml & 1.00 \\
Fe-EDTA, ml & 5.00 \\
Sucrose, ml & 30.00 \\
Nicotinic acid, mg & 5.00 \\
Pyridoxine, mg & 0.50 \\
Thiamine, mg & 5.00 \\
Inositol, mg & 100.00 \\
2,4-D, mg & 1.00 \\
Kinetin, mg & 0.10 \\
Agar, g & 20.00 \\
\hline
\end{tabular}

diameter. Table 2 shows the composition of the nutrient media.

[Table 2]

- Suspension cultures were obtained from callus cultures. The best growing loose callus cultures were selected for the experiments. Callus culture in the amount of 300$400 \mathrm{mg}$ was placed in flasks (per $250 \mathrm{ml}$ ) containing 25 $\mathrm{ml}$ ) milliliter( of liquid culture medium and cultured on a stationary circular rocker Incubated Shakers ISS4075 (Jeiotech, Republic of Korea) at 95-100 rpm. After 18-20 days of cultivation, the supravaginal fraction of the cells was replanted, gradually increasing the degree of dilution from $1 / 2$ to $1 / 8$ (the ratio of the volume of the inoculate to the volume of the fresh nutrient medium) and shortening the subcultivation cycle. Suspension cultures were grown on nutrient media, the composition of which is shown in Table 3.

[Table 3]

- In vitro root cultures of meadowsweet were obtained from sterile seedlings of plant seeds, namely, from the leaves obtained at the 1st stage of this work. The leaves were transformed using agrobacteria, according to the procedure of Novikova et al. (2020): the leaves were perforated with a sterile needle and located on a B5 culture medium (Gamborg et al., 1968), containing a suspension (OD600=0.4) agrobacteria. Before the transformation, the suspension culture of agrobacteria was increased on the YEB medium for one day in the dark, at $24{ }^{\circ} \mathrm{C}$ on a rocking chair with a circular rotation (amplitude 5-10 cm, rotation speed $90 \mathrm{rpm}$ ). As a control, we used needle-pierced explants placed on a solid medium B5 without applying a suspension of the microorganism. After 12-48 hours of exposure in a bacterial suspension, the explants were washed with sterile water, and all moisture was removed from them (dry) sterile filter paper and located on a solid medium B5 containing $500 \mathrm{mg} / 1$ of cefotaxime. The antibiotic was added to remove agrobacterium

Table 2. Composition of nutrient media that differ in the composition of growth regulators used in the experiment on the selection of optimal parameters for growing callus culture of meadowsweet.

\begin{tabular}{cccc}
\hline \multirow{2}{*}{ Components of the nutrient medium } & \multicolumn{3}{c}{ Value per 1 liter of distilled water } \\
\cline { 2 - 4 } & Nutrient medium No. 1 & Nutrient medium No. 2 & Nutrient medium No. 3 \\
\hline Macro salts MS 20x, ml & 50.00 & 50.00 & 50.00 \\
Micro salts SH 20x, ml & 1.00 & 1.00 & 1.00 \\
Fe-EDTA, ml & 5.00 & 5.00 & 5.00 \\
Thiamine, mg & 5.00 & 5.00 & 5.00 \\
Pyridoxine, mg & 0.50 & 0.50 & 0.50 \\
Nicotinic acid, mg & 5.00 & 5.00 & 5.00 \\
Sucrose, g & 30.00 & 30.00 & 30.00 \\
Inositol, mg & 100.00 & 100.00 & 100.00 \\
2,4-D, mg & - & 1.00 & 2.00 \\
Kinetin, mg & - & 0.10 & 0.20 \\
Agar, g & 20.00 & 20.00 & 20.00 \\
\hline
\end{tabular}


residues. After one month of cultivation, the number of transformations was estimated. It should be mentioned that the transformed explants were chosen based on phenotypic features. Subsequently, two passages of the obtained roots were performed on a solid medium B5, which did not contain hormones, but contained a reduction dose of cefotaxime ( $250 \mathrm{mg} / \mathrm{l})$.

Cultivation took place in the absence of light at a temperature of $+23^{\circ} \mathrm{C}$ on a rocker with a frequency of $100 \mathrm{rpm}$. Subsequent transplantation to a fresh medium was performed as soon as contamination with agrobacteria emerged. To obtain root cultures in vitro, $300 \mathrm{ml}$ flasks were used, the volume of the medium was $100 \mathrm{ml}$. The initial weight of the root culture in vitro was from 0.5 to $1.0 \mathrm{~g}$.

In this work, the following bacteria were used for the transformation of explants (Figure 2): strain No. 1 - Agrobacterium rhizogenes 15834 Swiss (Ufa, Russia), strain No. 2 - Agrobacterium rhizogenes 15834 Swiss (Timiryazev Institute of Plant Physiology, Russian Academy of Sciences, Russia), strain No. 3 - Agrobacterium rhizogenes 8196 (Czech Buduyevitsy, Czech Republic), grown on agarized culture medium YEB.

[Figure 2]
2.1. Study of the growth specifications of the obtained cell cultures in vitro

\subsubsection{Study of callus crop biomass growth}

The growth in Pi biomass was determined for a definite time of growing callus crops of meadowsweet (on the first day of cultivation) according to the relation 1 :

$$
P_{i}=\frac{X_{i}-X_{0}}{X_{0}}
$$

In which $X_{i}$ is the weight of the crop on the first day of cultivation and $X_{0}$ is the weight of the transplant)

\subsubsection{Study of growth specifications of suspension cultures}

For the most steadily growing suspension lines, the growth specifications were comprehensively investigated according to the following parameters:

The growth index (I) was determined, the method is presented in Vijendra et al. (2020), the growth index was presented using the relation 2 :

$$
I=\frac{X_{\max }}{X_{0}}
$$

Table 3. Composition of the nutrient medium for the cultivation of suspension crops of meadowsweet.

\begin{tabular}{cccc}
\hline \multirow{2}{*}{ Components of the nutrient medium } & \multicolumn{3}{c}{ Value per 1 liter of distilled water } \\
\cline { 2 - 4 } & Nutrient medium No. 1 & Nutrient medium No. 2 & Nutrient medium No. 3 \\
\hline${ }^{*}$ Macro salts MS 20x, ml & 50.00 & 50.00 & 50.00 \\
${ }^{* *}$ Micro salts SH 20x, ml & 1.00 & 1.00 & 1.00 \\
Fe-EDTA, ml & 5.00 & 5.00 & 5.00 \\
Thiamine, mg & 5.00 & 5.00 & 5.00 \\
Pyridoxine, mg & 0.50 & 0.50 & 0.50 \\
Nicotinic acid, mg & 5.00 & 5.00 & 5.00 \\
Sucrose, g & 30.00 & 30.00 & 30.00 \\
Inositol, mg & 100.00 & 100.00 & 100.00 \\
2,4-D, mg & - & 1.00 & 2.00 \\
Kinetin, mg & - & 0.10 & 0.20 \\
\hline
\end{tabular}

*on (Murashige and Skoog, 1962). **on (Schenk and Hildebrandt, 1972).

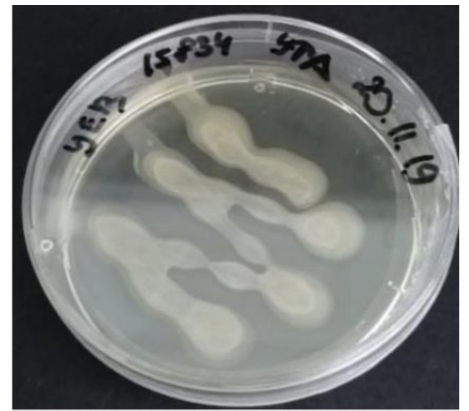

a)

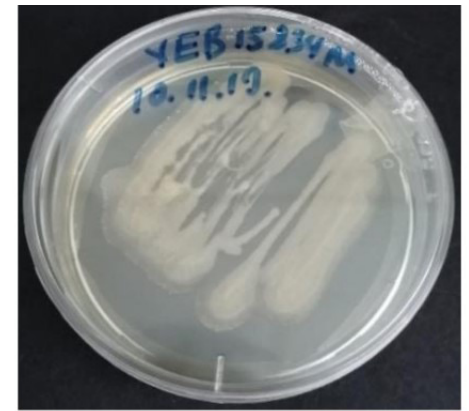

b)

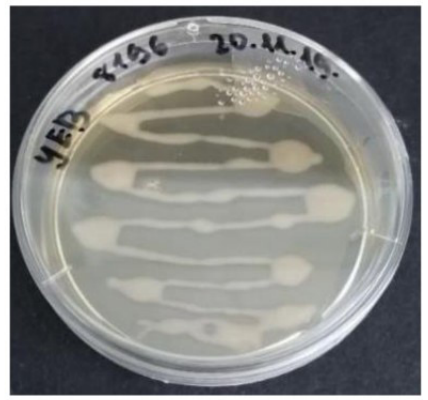

c)

Figure 2. Agrobacterium strains used to transform the leaves of seed seedlings into roots: a) Strain No. 1-Agrobacterium rhizogenes 15834 Swiss (Ufa, Russia); b) Strain No. 2-Agrobacterium rhizogenes 15834 Swiss (Timiryazev Institute of Plant Physiology, Russian Academy of Sciences, Russia); c) Strain No. 3-Agrobacterium rhizogenes 8196 (Czech Buduyevitsy, Czech Republic). 
In which $\mathrm{X}_{\max }$ is the maximum value of one of the growth criteria, and $\mathrm{X}_{0}$ is the initial value of one of the growth criteria.

The specific growth rate in the exponential growth phase (relation 3) (Nhut et al., 2013; Trong et al., 2017).

$$
\mu=\frac{\operatorname{In} X_{2}-\operatorname{In} X_{1}}{X_{0}} \div\left(t_{2}-t_{1}\right), \text { day }^{-1}
$$

In which $\mathrm{X} 2$ is the content of dry biomass in a liter of the medium at time $\mathrm{t} 2$;

$\mathrm{X} 1$ is the content of dry biomass in a liter of the medium at time $\mathrm{t} 1$;

$\mathrm{t} 1$ is the start time of the exponential growth phase, day; t2 is the end time of the exponential growth phase, day.

It should be mentioned that the subcultivation cycle in specifying the growth characteristics was 20-32 days. To characterize the growth of root crops, the growth index indicator was used.

\subsection{Study of the qualitative and quantitative composition} of BAS in the biomass of the obtained crops of meadowsweet (Filipendula ulmaria)

Analysis of the quantitative and qualitative composition of BAS by HPLC. The analysis was carried out on a Shimadzu LC-20 Prominence chromatograph (Shimadzu Corp., Japan) with a Shimadzu SPD-20-MA diodematrix detector (Shimadzu Corp., Japan) and a RID-10A refractometric detector (Shimadzu Corp., Japan). We used a chromatographic column Kromasil 5 microns C18, $250 \times 4.6 \mathrm{~mm}$ (Akzo Nobel Pulp and Performance Chemicals AB, Sweden); a pre-column Security Guard Gartridge, injection volume $20 \mu \mathrm{l}$. Column temperature $300{ }^{\circ} \mathrm{C}$. The elution mode is isocratic, and PF consists of- $\mathrm{AcCN}$ : IPS: H2O - H3PO4 (20:5:75 pH 3.5).

Sample preparation: $2 \mathrm{ml}$ of the sample was located in a conical flask with a capacity of $100 \mathrm{ml}, 20 \mathrm{ml}$ of methyl alcohol was added. The suspension was treated with ultrasound using an Elmasonic $\mathrm{S} 6 \mathrm{OH}$ ultrasonic washing machine (Elma, Germany) for 5 minutes, then $20 \mathrm{ml}$ of $1.5 \mathrm{M}$ hydrochloric acid solution was added, and hydrolysis was performed in a boiling water bath EKROS PE-4310 (EKROSHIM, Russia) with a reverse refrigerator for 30 minutes. The resulting solution was cooled to room temperature, then transferred to a measuring flask with a capacity of $100 \mathrm{ml}$; the volume of the solution was brought to the mark with methyl alcohol, mixed, and filtered through a paper filter "yellow tape" (JSC KZPO, Russia). They were evaporated under vacuum using a rotary vaporizer IR-1LT (Labtex, Russia) to a dry residue and dissolved in $2 \mathrm{ml}$ of the mobile phase.

The relative standard deviation was calculated for the peak areas of quercetin (Sigma cat \# 0125) and kaempferol (Sigma cat \# K0133) from five chromatograms; the deviation did not exceed $0.5 \%$. The efficiency of the chromatographic column, calculated according to the standards of quercetin and kaempferol, was more than 10,000 theoretical plates.
2.3. Survey of the qualitative and quantitative composition of BAS in alcohol extracts obtained from callus cultures in vitro of the meadowsweet (Filipendula ulmaria)

To obtain extracts from the biomass of callus cultures in vitro, three $g$ of dried and crushed biomass was poured with $260 \mathrm{ml}$ of the extractant-ethyl alcohol (Kemerovo Pharmaceutical Factory, Russia) using a mill of the brand LZM - 1M (Russia, Olis) (Dyshlyuk et al., 2020a, b). Extraction was performed out on a water bath of the PE-4310 brand (EKROSHIM, Russia) with a reverse refrigerator under static conditions. Cell cultures are dried at a temperature of $59 \pm 2{ }^{\circ} \mathrm{C}$ to a residual humidity of 10-15\%. The extraction parameters are shown in Table 4.

The analysis of the qualitative and quantitative composition of BAS in extracts obtained from the biomass of callus cultures in vitro of meadowsweet was carried out using the methods:

- TLC. The analysis was performed on Sorbfil PTS-AF-A plates (Labtech, Russia). The development of a solution of phosphoric-tungstic acid $25 \%$, followed by heating at $95{ }^{\circ} \mathrm{C}-10 \mathrm{~min}$. The densitometric analysis of the plate was carried out using a densitometer with a Sony photo fixing system (Handycam HDR-CX405), IMID LLC, Russia).

- HPLC on a Shimadzu LC-20 Prominence chromatograph (Shimadzu Corp., Japan). The analysis was performed based on the method described above in item 6 .

- HPLC on a chromatograph Color Yauza-04 (Chemautomatika, Russia). We used a UV / VID detector with a photodiode array with specified wavelengths of $255,280 \mathrm{~nm}$. Control of the device and processing of the received data was performed using the MulticHrom software, version 3.1.1550 (CJSC Ampersend, Russia), column: Gemini 5mkm C18 110A, size 250x4.6 mm (Phenomenex (USA)), pre-column Analitical Guard (KJO -4282).

Table 4. Parameters of extraction of biomass of cell cultures of meadowsweet (Filipendula ulmaria).

\begin{tabular}{cccc}
\hline & \multicolumn{3}{c}{$\begin{array}{c}\text { Callus cultures of meadowsweet } \\
\text { (Filipendula ulmaria) }\end{array}$} \\
\cline { 2 - 4 } No. & $\begin{array}{c}\text { Temperature, } \\
{ }^{\circ} \mathbf{C}\end{array}$ & $\begin{array}{c}\text { Volume } \\
\text { fraction of } \\
\text { ethanol, \% }\end{array}$ & $\begin{array}{c}\text { Extraction } \\
\text { time, h }\end{array}$ \\
\hline 1 & 30 & 70 & 2 \\
2 & 30 & 70 & 4 \\
3 & 30 & 30 & 6 \\
4 & 30 & 70 & 6 \\
5 & 50 & 70 & 2 \\
6 & 50 & 30 & 6 \\
7 & 50 & 70 & 6 \\
8 & 70 & 70 & 6 \\
9 & 35 & 70 & \\
\hline
\end{tabular}


2.4. Study of antioxidant and antimicrobial properties of extracts obtained from callus cultures of meadowsweet

The determination of the antioxidant activity of alcohol extracts was performed out based on the method described in Moharram and Youssef (2014). In a flask for titration with a capacity of $50 \mathrm{ml}, 8 \mathrm{ml}$ of freshly boiled and cooled distilled water, $1 \mathrm{ml}$ of $20 \%$ sulfuric acid solution, $1 \mathrm{ml}$ of $0.05 \mathrm{~N}$ potassium permanganate solution were added and mixed. Titration was carried out with a micropipette ( $1 \mathrm{ml}$ volume with a division price of $0.01 \mathrm{ml}$ ) titrated with the test extract until the pink color of potassium permanganate disappeared. The volume of the extract used for titration was recorded and converted to quercetin: $1 \mathrm{ml}$ of $0.05 \mathrm{~N}$ potassium permanganate solution corresponded to $0.25 \mathrm{mg}$ of quercetin.

Study of antimicrobial activity of alcohol extracts in relation to sanitary-indicative microorganisms (test cultures): Escherichia coli ATCC 25922, Candida albicans Y-3108, Bacillus cereus B-6644, Pseudomonas aeruginosa B6643, Enterococcus faecium 170M39, Klebsiella pneumonia CECT 143, Helicobacter pylori J99, Streptococcus viridans ATCC 11563, Streptococcus bovis D ATCC 49147, Porphyromonas gingivalis ATCC 33277, Acinetobacter baumannii ATCC 19606, Streptococcus intermedius TYG 1620 . The analysis was performed using the disc-diffusion method described in Milentyeva et al. (2020), only instead of disks with antibiotics, sterile disks impregnated with $10 \mu$ of the studied extracts were used. The disks were applied to an agarized medium of MPA, sown with a lawn test culture (a suspension with a density of 0.5 according to McFarland was used, the density was determined using a densimeter DEN-1 (BioSan, Latvia)). As a control, a disk with a nutrient medium of MPA was applied; as a comparison, a disk with an antibiotic (ampicillin $10 \mathrm{mcg}$ - HiMedia Laboratories, India) was used. The cups were incubated at $37^{\circ} \mathrm{C}$ for 24 hours. After the incubation time, the diameter of the transparent zone (in $\mathrm{mm}$ ) of the absence of bacterial growth around the disk was measured.

The presence of a growth suppression zone indicated the presence of antagonistic activity: in the inhibition zone with a diameter of less than $11 \mathrm{~mm}$, the strain showed no activity, 11-16 mm strain showed weak activity, 17-22 mm-medium activity, and more than $23 \mathrm{~mm}$-high activity (Jomehzadeh et al., 2020).

\section{Results and Discussion}

\subsection{Results of germination of sterile seeds of meadowsweet}

Figure 3 shows sprouted sterile seeds of meadowsweet. The first seed seedlings were observed after 4-5 weeks of cultivation.

[Figure 3]

\subsection{Results of the formation of callus cultures of} Filipendula ulmaria cells grown on various nutrient media

The formation of primary callus from sprouted sterile seeds on the considered nutrient media was observed on the 7-14 days of cultivation. The results of cultivation - and the resulting growth index for dry biomass are presented in Table 5.

[Table 5]

The results indicate that the highest growth index for dry biomass is observed when growing cell cultures on nutrient medium No. 2 (Figure 4).

[Figure 4]

The callus grown on medium No. 2 had a more stable growth phase and a less loose shape than the callus obtained

Table 5. Results of the study of the growth index of the obtained callus crops grown on various nutrient media.

\begin{tabular}{ccc}
\hline Medium & $\begin{array}{c}\text { Duration of the } \\
\text { subcultivation cycle, } \\
\text { day }\end{array}$ & $\begin{array}{c}\text { Dry biomass growth } \\
\text { index }\end{array}$ \\
\hline No. 1 & $28-32$ & $8.5-10.3$ \\
No. 2 & $28-32$ & $9.7-13.6$ \\
No. 3 & $28-32$ & $9.5-12.9$ \\
\hline
\end{tabular}
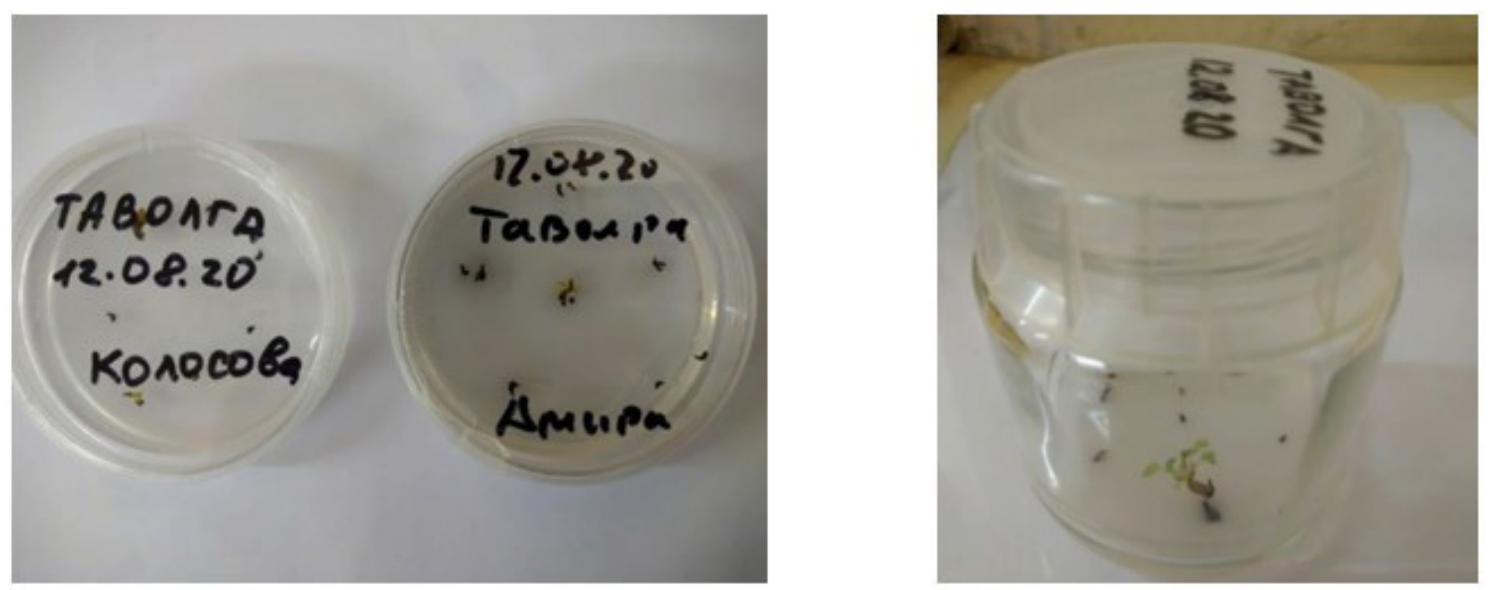

Figure 3. Germination process of sterile seeds of meadowsweet (Filipendula ulmaria). 
on media No. 1 and No. 3. Also, as a result of the study, it was found that there were no significant differences in the intensity of seed germination on the media used for callus formation.

\subsection{The results of the formation of suspension cultures of meadowsweet}

In the process of obtaining suspension cell cultures, intensive formation of a fine superdeposition fraction and rapid adaptation of the culture to new growing conditions were observed. The growing cycle of suspension crops was 2-3 weeks. After 1.5-2.0 months from the moment of receiving the first cell suspensions, the length of the subcultivation cycle was 14 days with an initial planting density of an average of 1.0-1.5 g / 1 for the dry mass of cells. The results of studies on the selection of the optimal composition of the nutrient medium for the cultivation of suspension cultures of plant cells are presented in Table 6 .

[Table 6]

The main growth characteristics of suspension cultures obtained during cultivation on various nutrient media are presented in Table 7.

[Table 7]

The results presented in the table indicate that the optimal medium for obtaining stable suspension cultures is medium No.2. The obtained suspension cell cultures are shown in Figure 5.

[Figure 5]

\subsection{Results of formation of root cultures in vitro of the} meadowsweet (Filipendula ulmaria)

The results of the transformation of the explants of Filipendula ulmaria by different strains of Agrobacterium rhizogenes are presented in Table 8 .

Analysis of the transformation results shows that the explants of meadowsweet form root cultures in vitro

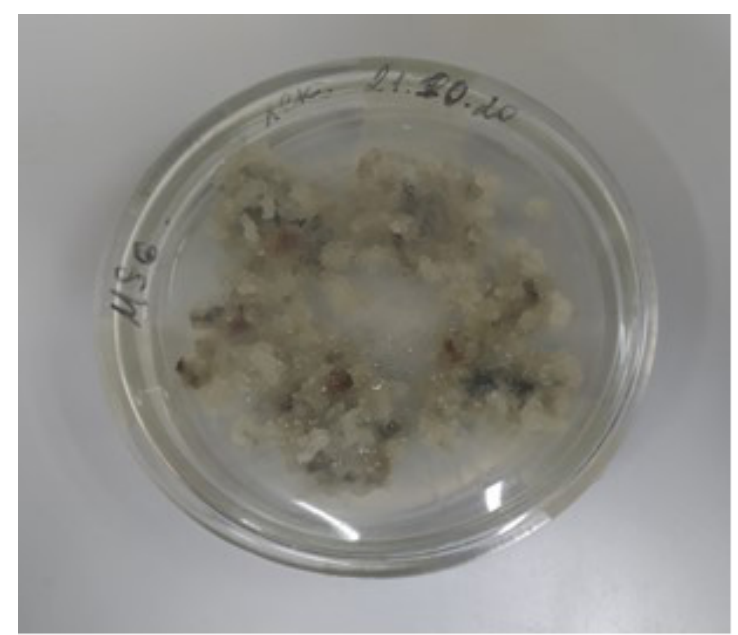

Figure 4. Callus cell cultures of meadowsweet (Filipendula ulmaria) grown on nutrient medium No. 2.

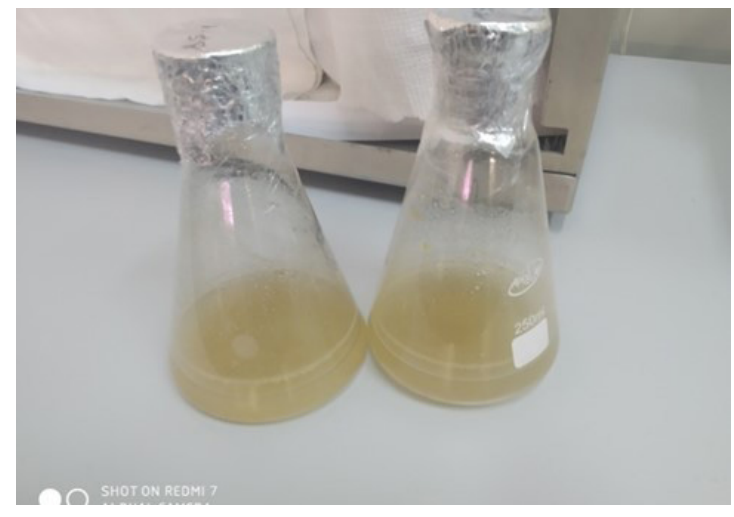

Figure 5. Suspension cultures of meadowsweet (Filipendula ulmaria) cells grown on nutrient medium No. 2 .

Table 6. Results of determining the viability of primary suspension cell cultures, cell units.

\begin{tabular}{cccc}
\hline Name of the medicinal plant & Nutrient medium No. 1 & Nutrient medium No. 2 & Nutrient medium No.3 \\
\hline $\begin{array}{c}\text { Meadowsweet vyazolistnaya } \\
\text { (Filipendula ulmaria) }\end{array}$ & $23.600 \pm 0.001$ & $46.700 \pm 0.020$ & $9.800 \pm 0.001$ \\
\hline
\end{tabular}

Table 7. Results of the study of the growth characteristics of suspension cultures of meadowsweet cultivated on various nutrient media.

\begin{tabular}{ccccc}
\hline Nutrient medium & $\mathbf{X}_{\max }, \mathbf{g} / \mathbf{l}$ & $\mathbf{v}, \%$ & $\mu_{\mathbf{d w}{ }^{\prime}} \mathbf{d a y}^{-\mathbf{1}}$ & $\mathbf{I}_{\mathbf{d w}}$ \\
\hline No. 1 & $7.52-11.96$ & $72-80$ & $0.10-0.13$ & $7.63-8.93$ \\
No. 2 & $7.65-12.32$ & $72-85$ & $0.11-0.15$ & $7.80-9.13$ \\
No. 3 & $7.2-11.2$ & $70-79$ & $0.11-0.12$ & $7.35-8.36$ \\
\hline
\end{tabular}

Table 8. Number of explants formed, transformed with the help of various agrobacteria.

\begin{tabular}{lcccc}
\hline Strain & Control & $\begin{array}{c}\text { Total number of explants } \\
\text { used in experiments, pcs }\end{array}$ & Number of explants with roots, pcs & \% explants \\
\hline No. 1 & 0 & 36 & 1 & 2.778 \\
No. 2 & 0 & 36 & 3 & 8.333 \\
No. 3 & 0 & 36 & 1 & 2.778 \\
\hline
\end{tabular}


with different intensities when using different strains of Agrobacterium rhizogenes: the largest number of transformed explants was obtained when using the Agrobacterium rhizogenes strain 15834 Swiss (Moscow, Russia). Figure 6 shows an in vitro root culture of meadowsweet obtained using Agrobacterium rhizogenes 15834 Swiss (Moscow, Russia). The results of the study of changes in the growth index of root crops of the plant are shown in Figure 7.

[Figure 7]

The analysis of the results shows that the growth curve of the root culture in vitro of meadowsweet had an S-shape, included standard growth phases, and was characterized by a long exponential and stationary phase (from 28 to 42 days of cultivation), after which the stage of degradation began, at which the growth rate of the culture decreased, and consequently, the amount of biomass decreased. The root culture growth index was 32 .

\subsection{Results of the study of the qualitative and quantitative} composition of BAS in the biomass of the obtained crops of meadowsweet (Filipendula ulmaria)

The results of the study of the quantitative and qualitative composition of biologically active substances in the biomass of the obtained root cultures, suspension, and callus, in vitro of meadowsweet are presented in Figure 8.

[Figure 8]

The results show that the highest content of BAS is observed in the biomass of callus cultures of the plant in comparison with suspension and root cultures in vitro: thus, flavonoids in the biomass of callus crops contain 1.4 times more than in the biomass of suspension crops and 1.2 times more than in the biomass of root crops; vitamin C E in the biomass of callus crops is 1.4 times more than in suspension crops and 1.3 times more than in the biomass of root crops; phenolic acids in the biomass of callus crops are 1.3 times more than in the biomass of suspension crops and 1.2 times more than in the biomass of root crops; carotenoids in the biomass of callus crops are 1.5 times more than in the biomass of suspension crops and 1.6 times more than in the biomass of root crops; essential oils in the biomass of callus crops are 1.6 times more than in the biomass of suspension crops and 1.2 times more than in the biomass of root crops; glycosides in the biomass of callus crops are 1.0 times more than in the biomass of suspension crops and 1.3 times more than in the biomass of root crops. Therefore, in further study, it is rational to use the biomass of callus cultures of meadowsweet.

3.6. Results of the study of the qualitative and quantitative composition of BAS of alcohol extracts obtained from the biomass of callus cultures in vitro of meadowsweet (Filipendula ulmaria)

Under the conditions of specific TLC reactions (Waksmundzka-Hajnos et al., 2008), the content of amiran, oleanolic and ursolic acids was determined in triterpenoids the studied samples. The identified substances correspond to the values of $\mathrm{Rf}=0.03 ; 0.86 ; 095$, which are shown on the densitogram (Figure 9).

[Figure 9]
According to the HPLC analysis, it was found that the test samples contain quercetin and its glycosidated forms

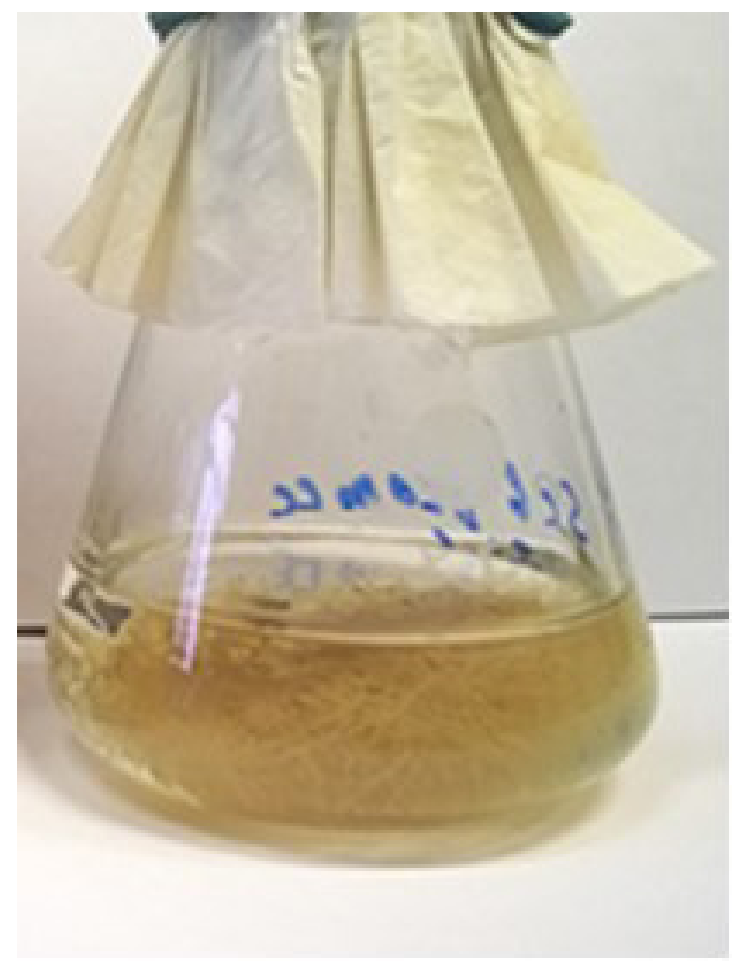

Figure 6. In vitro root cultures of meadowsweet (Filipendula ulmaria), cultivation duration 5 weeks.

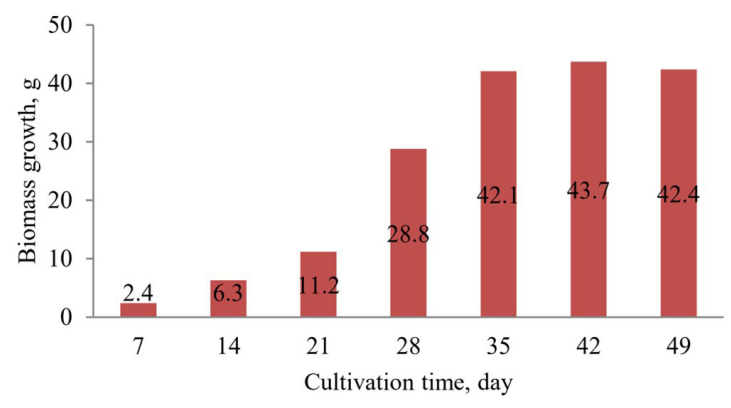

Figure 7. Results of the study of changes in the growth index of root culture in vitro ofmeadowsweet (Filipendula ulmaria).

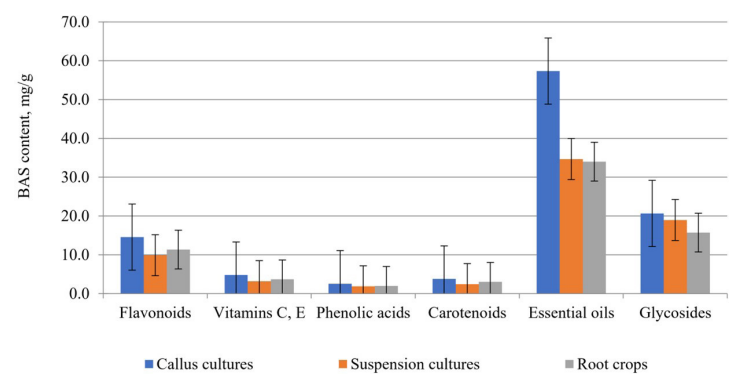

Figure 8. Composition of BAS in the biomass of callus, suspension and root crops of meadowsweet (Filipendula ulmaria). 
(Figure 10).

[Figure 10]

The components and their retention time are shown in Table 9, and Figure 11 shows the UV spectrum of the BAS of avicularin.

[Table 9]

[Figure 11]

A similar characteristic of the extract components is observed under the conditions of amperometric detection performed on the Tsvet-Yauza-04 chromatograph on Kromasil octadicylsilicagel (Germany). In this case, the amperometric detector, having a higher sensitivity, allowed detecting the content of quercetin, other flavonoids, phenols, and their derivatives. The chromatogram is shown in Figure 12. The detailed content of the components is given in Table 10.

[Figure 12]

[Table 10]

Table 9. Content of components in the extract of callus cultures of meadowsweet (Filipendula ulmaria) according to HPLC data with matrix.

\begin{tabular}{cccc}
\hline Peak no. & Holding time, min & Component Name & $\begin{array}{c}\text { Quantitative content, } \\
\text { mg } / \mathbf{m l}\end{array}$ \\
\hline 1 & 5.25 & gallic acid & $6.70 \pm 0.21$ \\
2 & 6.50 & 4-hydroxybenzoic acid & $11.87 \pm 0.76$ \\
3 & 6.90 & 2-methoxyphenol & $4.52 \pm 0.50$ \\
4 & 7.41 & pyrocatechin & $5.33 \pm 0.50$ \\
5 & 8.11 & 4 -venyl-2-methoxyphenol & $4.51 \pm 0.50$ \\
6 & 9.62 & benzaldehyde & $2.17 \pm 0.20$ \\
7 & 10.07 & spireoside & $15.39 \pm 0.72$ \\
8 & 12.30 & avicularin & $21.33 \pm 0.86$ \\
9 & 12.59 & hyperoside & $9.80 \pm 0.50$ \\
10 & 14.67 & salicylic acid & $3.47 \pm 0.14$ \\
\hline
\end{tabular}

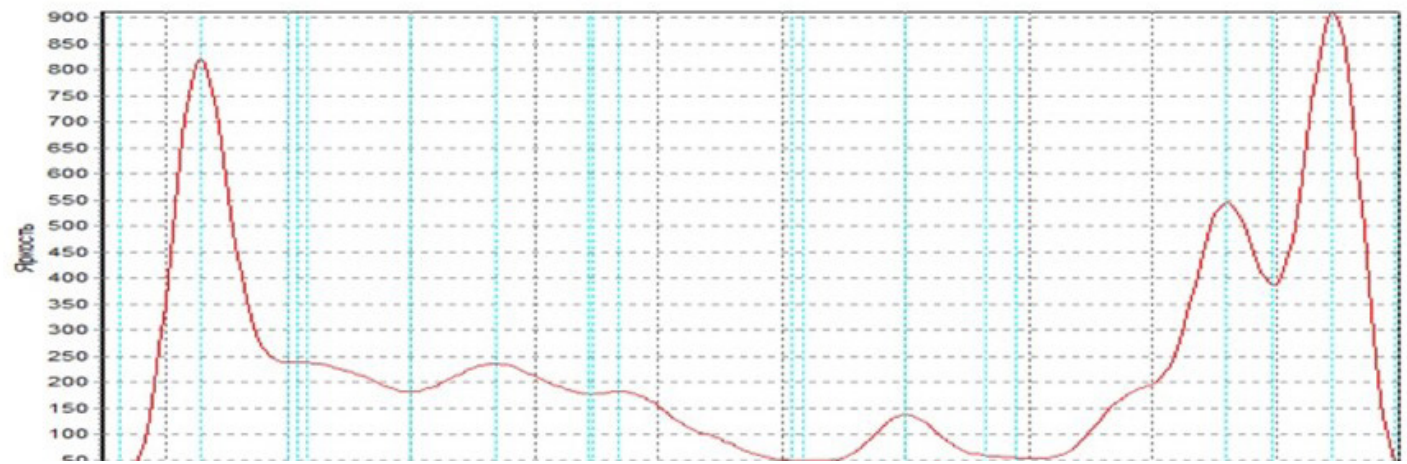

Figure 9. Densitogram of the extract of callus cultures of meadowsweet (Filipendula ulmaria).

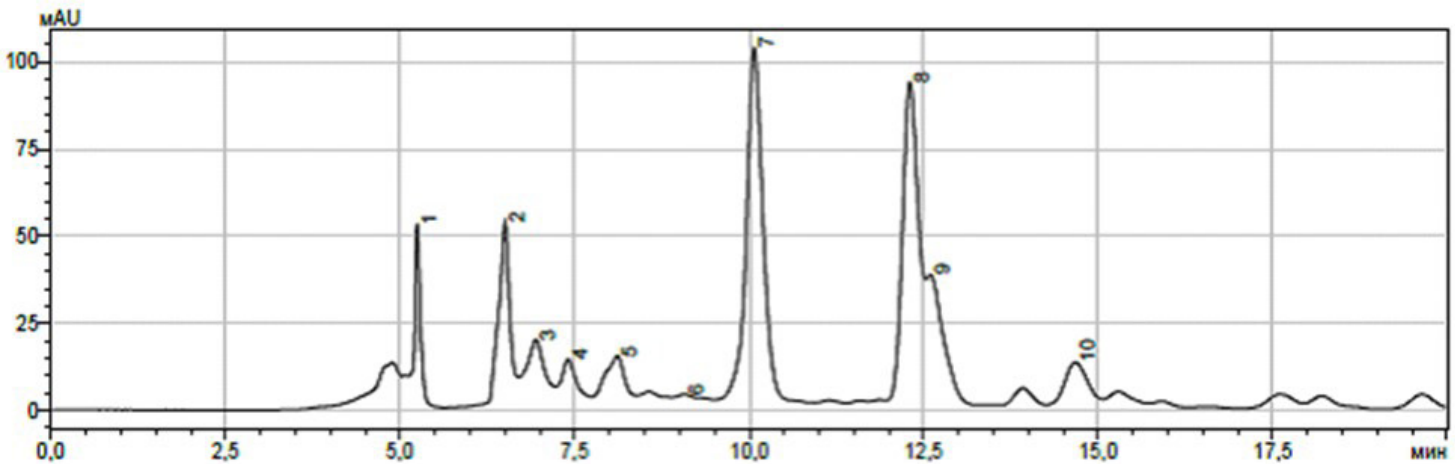

Figure 10. HPLC chromatogram of the extract of callus cultures of meadowsweet (Filipendula ulmaria): 1 - gallic acid, 2 - 4-hydroxybenzoic acid, 3 - 2-methoxyphenol, 4 - pyrocatechin, 5 - 4-venyl-2-methoxyphenol, 6 - benzaldehyde, 7 - spireoside, 8 - avicularin, 9 - avicularin, 10 - m-hydroxybenzoic acid. 


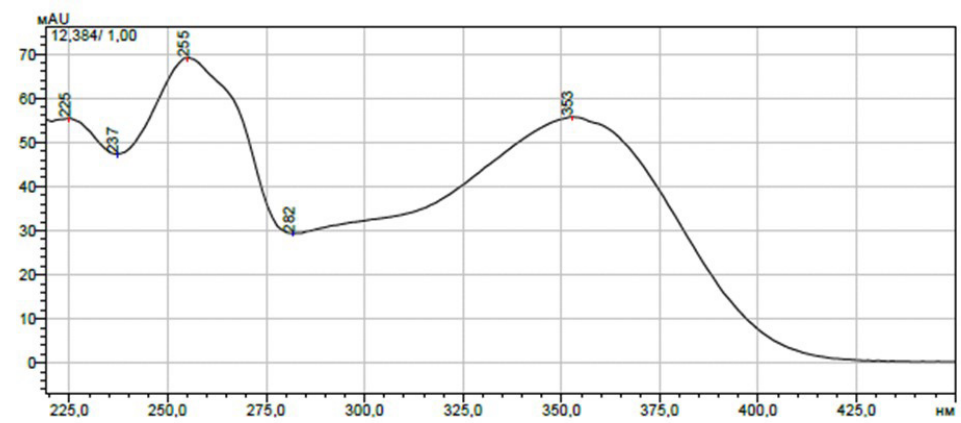

Figure 11. UV spectrum of avicularin.

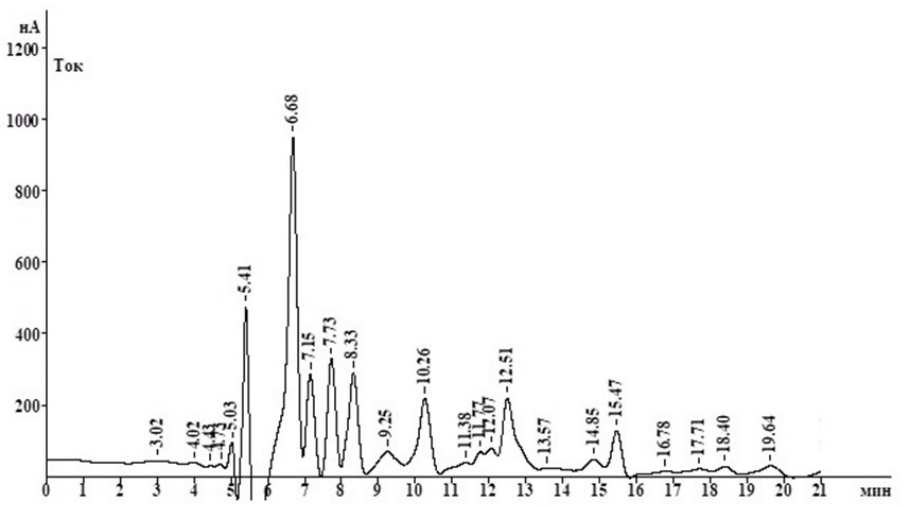

Figure 12. Chromatogram of a sample of the extract of callus cultures of meadowsweet (Filipendula ulmaria) under the conditions of amperometric detection with a glass-carbon electrode voltage of $0.85 \mathrm{~V}$.

Table 10. Content of individual components in samples of alcohol extracts from the biomass of callus cultures of Filipendula ulmaria according to amperometric detection data.

\begin{tabular}{ccc}
\hline $\begin{array}{c}\text { Holding } \\
\text { time, min }\end{array}$ & Component Name & $\begin{array}{c}\text { Quantitative } \\
\text { content, } \mathbf{~ m g} / \mathbf{m l}\end{array}$ \\
\hline 5.41 & gallic acid & $6.50 \pm 0.36$ \\
6.68 & 4-hydroxybenzoic acid & $11.91 \pm 0.76$ \\
7.15 & 2-methoxyphenol & $4.54 \pm 0.40$ \\
7.73 & pyrocatechin & $5.31 \pm 0.71$ \\
8.33 & 4-venyl-2- & $4.52 \pm 0.50$ \\
& methoxyphenol & \\
9.25 & benzaldehyde & $2.21 \pm 0.05$ \\
10.26 & spireoside & $15.41 \pm 0.86$ \\
12.51 & avicularin & $21.3 \pm 0.72$ \\
15.47 & salicylic acid & $9.85 \pm 0.50$ \\
19.64 & quercetin & $3.52 \pm 0.14$ \\
\hline
\end{tabular}

According to TLC and HPLC, amiran, oleanolic and ursolic acids, gallic acid, quercetin, 4-hydroxybenzoic acid, 2-methoxyphenol, pyrocatechin, 4-venyl-2-methoxyphenol, benzaldehyde, spireoside, avicularin, hyperoside and salicylic acid are contained.
Table 11. Results of the study of the antioxidant activity of alcoholic extracts of the callus culture of meadowsweet (Filipendula ulmaria).

\begin{tabular}{cc}
\hline Extract no. & Antioxidant activity, $\mathbf{~ m g} / \mathbf{g}$ \\
\hline 1 & $0.3490 \pm 0.0022$ \\
2 & $0.3920 \pm 0.0022$ \\
3 & $0.3730 \pm 0.0025$ \\
4 & $0.3380 \pm 0.0027$ \\
5 & $0.3910 \pm 0.0025$ \\
6 & $0.3780 \pm 0.0023$ \\
7 & $0.3520 \pm 0.0031$ \\
8 & $0.3790 \pm 0.0027$ \\
9 & $0.3700 \pm 0.0017$ \\
\hline
\end{tabular}

3.7. Results of the study of the antioxidant and antimicrobial activity of extracts of callus cultures of meadowsweet

Table 11 shows the results of determining the antioxidant activity (based on the quercetin content). The results show that alcohol extracts obtained from the biomass of the callus culture of meadowsweet show antioxidant activity. The most active extracts were No.2 and No. 5.

[Table 11]

Table 12 shows the results of determining the antimicrobial activity of alcohol extracts from callus cultures 


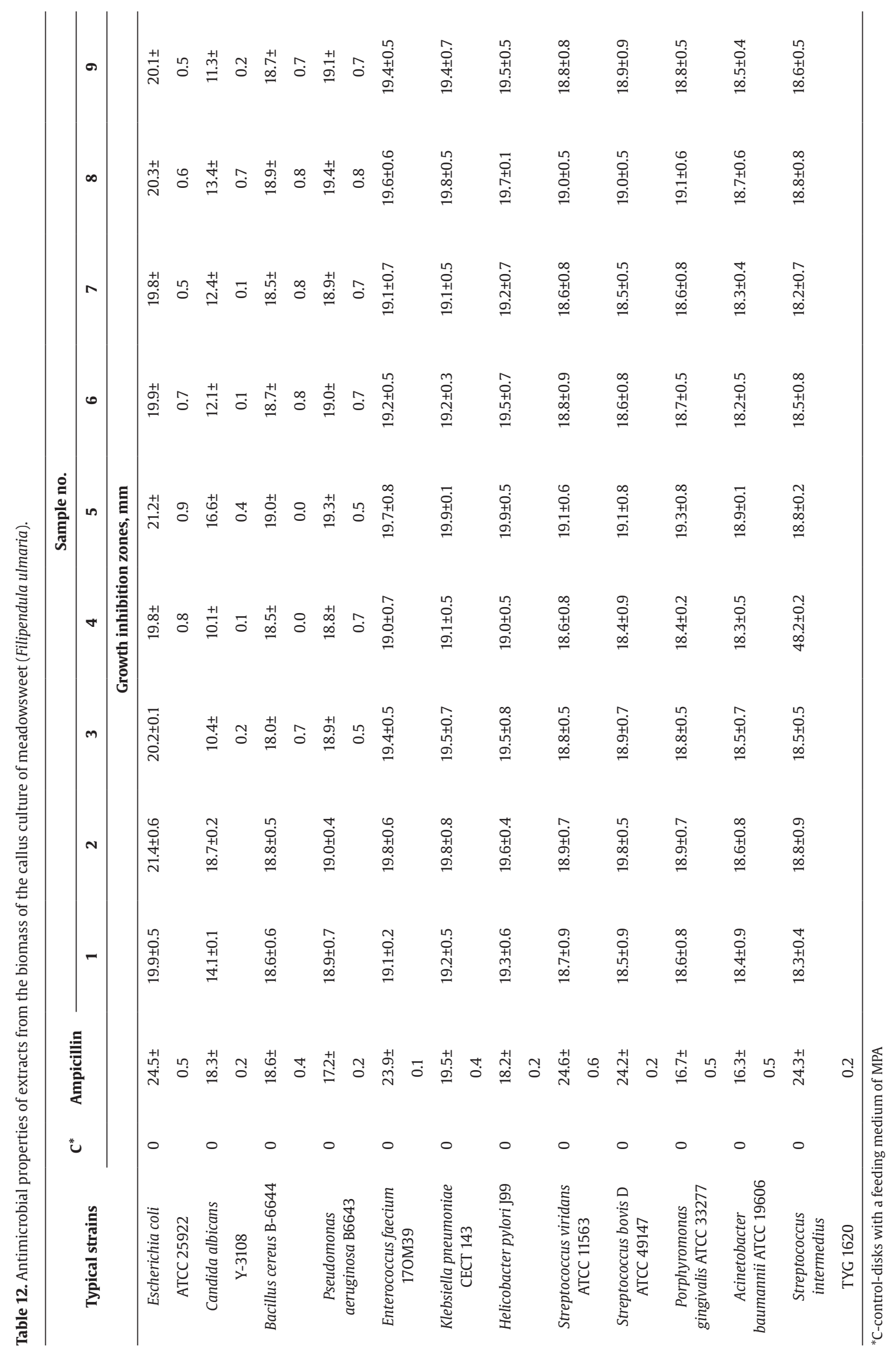


of meadowsweet to a number of sanitary-significant strains. The results show that the greatest activity is observed in extracts that showed great antioxidant properties-these are samples No. 2, 5, 8. Basically, a number of alcoholic extracts of the callus culture of meadowsweet show average antimicrobial activity in relation to a number of the strains under consideration. But with respect to Candida albicans Y-3108, samples No. 3 and No. 4 have no antimicrobial activity, and all other samples (except No. 2 , which has medium activity) have weak activity with respect to this strain.

[Table 12]

Due to the content of BAS showing antimicrobial and antioxidant properties in alcohol extracts obtained from callus cultures of meadowsweet, this plant can be used as a raw material for the extraction of substances showing geroprotective properties. Such BAS can later be used as additives in functional food products to increase healthy life expectancy (Bhatti et al., 2020; Das et al., 2020; Martel et al., 2021; Muscat and Barrientos, 2020; Zhou et al., 2021).

\section{Conclusion}

Prevention of population aging is an important scientific task of modern society due to the increase in life expectancy, but not the improvement of its quality. One of the promising ways to solve this problem is expressed in the systematic use of geroprotectors. In this study, cell cultures in vitro and alcohol extracts from the plant Filipendula ulmaria were considered as raw materials rich in candidate substances for geroprotectors. According to the results of this study, cell cultures of in vitro meadowsweet contain flavonoids, vitamins $\mathrm{C}$ and $\mathrm{E}$, phenolic acids, carotenoids, essential oils and glycosides-substances that exhibit antimicrobial and antioxidant activity, which in the future can be used as geroprotectors. The most abundant BAS cell culture is the callus biomass, which was obtained when cultured on a nutrient medium with hormones of the following composition: macrosols MS 20x - $50.00 \mathrm{ml}$, microsols $\mathrm{SH}-1.00 \mathrm{ml}$, Fe-EDTA - $5.00 \mathrm{ml}$, thiamine $-5.00 \mathrm{mg}$, pyridoxine $-0.50 \mathrm{mg}$, nicotinic acid $-5.00 \mathrm{mg}$, sucrose - 30.00 g, inositol - $100.00 \mathrm{mg}, 2,4-\mathrm{D}-1.00 \mathrm{mg}$, kinetin - $0.10 \mathrm{mg}$, agar - 20,00 g, water - $1000 \mathrm{ml}$. According to TLC and HPLC data, alcohol extracts from the biomass of Filipendula ulmaria callus are rich in hydroxybenzoic and salicylic acids, spireoside, avicularin and hyperoside. In the future, the authors plan to extract these substances, with their further purification, study their chemical composition, safety indicators, and study the geroprotective properties of these substances on model nematode organisms (Caenorhabditis elegans).

\section{Acknowledgements}

The work was carried out within the framework of the state task FZSR-2020-0006 "Screening of biologically active substances of plant origin with geroprotective properties and development of technology for producing nutraceuticals that slow down aging".

\section{References}

ASYAKINA, L.K., BABICH, O.O., PUNGIN, A.V., PROSEKOV, A.Y., POPOV, A.D. and VOBLIKOVA, T.V. 2020. Optimization of extraction parameters of biologically active substances from dried biomass of callus, suspension cells and root cultures in vitro. In: IOP Conference Series: Earth and Environmental Science, 22 October 2020, Veliky Novgorod, Russian Federation. Bristol: IOP Publishing, p. 012008. http://dx.doi.org/10.1088/17551315/613/1/012008.

BARANENKO, D., BESPALOV, V., NADTOCHII, L., SHESTOPALOVA, I., CHECHETKINA, A., LEPESHKIN, A. and ILINA, V., 2019. Development of encapsulated extracts on the basis of meadowsweet (Filipendula ulmaria) in the composition of functional foods with oncoprotective properties. Agronomy Research (Tartu), vol. 17, no. 5, pp. 1829-1838.

BHATTI, G.K., REDDY, A.P., REDDY, P.H. and BHATTI, J.S., 2020. Lifestyle modifications and nutritional interventions in agingassociated cognitive decline and Alzheimer's disease. Frontiers in Aging Neuroscience, vol. 11, pp. 369. http://dx.doi.org/10.3389/ fnagi.2019.00369. PMid:31998117.

CAMPISI, J., KAPAHI, P., LITHGOW, G.J., MELOV, S., NEWMAN, J.C. and VERDIN, E., 2019. From discoveries in ageing research to therapeutics for healthy ageing. Nature, vol. 571, no. 7764, pp. 183-192. http://dx.doi.org/10.1038/s41586-019-1365-2. PMid:31292558.

CRISTIANO, G., MURILLO-AMADOR, B. and LUCIA, B., 2016. Propagation techniques and agronomic requirements for the cultivation of Barbados Aloe (Aloe vera (L.) Burm. F.): a review. Frontiers in Plant Science, vol. 7, pp. 1410. http://dx.doi. org/10.3389/fpls.2016.01410. PMid:27721816.

DAS, G., PARAMITHIOTIS, S., SIVAMARUTHI, B.S., WIJAYA, C.H., SUHARTA, S., SANLIER, N., SHIN, H.-S. and PATRA, J.K., 2020. Traditional fermented foods with anti-aging effect: a concentric review. Food Research International, vol. 134, pp. 109269. http:// dx.doi.org/10.1016/j.foodres.2020.109269. PMid:32517898.

DYSHLYUK, L., DMITRIEVA, A., IVANOVA, S., GOLUBTSOVA, Y. and OSTROUMOV, L., 2020a. Panax ginseng callus, suspension, and root cultures: extraction and qualitative analysis. Foods and Raw Materials, vol. 8, no. 2, pp. 369-376. http://dx.doi. org/10.21603/2308-4057-2020-2-369-376.

DYSHLYUK, L.S., FEDOROVA, A.M., DOLGANYUK, V.F. and PROSEKOV, A.Y., 2020b. Optimization of extraction of polyphenolic compounds from medicinal Lungwort (Pulmonaria officinalis L.). Journal of Pharmaceutical Research International, vol. 32, no. 24, pp. 36-45. http://dx.doi.org/10.9734/jpri/2020/v32i2430807.

DYSHLYUK, L.S., FEDOROVA, A.M., LOSEVA, A.I. and EREMEEVA, N.I., 2021. Callus cultures of Thymus vulgaris and Trifolium pratense as a source of geroprotectors. Food Processing: Techniques \& Technology, vol. 51, no. 2, pp. 423-432. http:// dx.doi.org/10.21603/2074-9414-2021-2-423-432.

FIGUEIREDO, J.A.S., DRUMM, E., RODRIGUES, M.A.S. and SPILKI, F.R., 2010. The Rio dos Sinos watershed: an economic and social space and its interface with environmental status. Brazilian Journal of Biology = Revista Brasileira de Biologia, vol. 70, no. 4, suppl., pp. 1131-1136. http://dx.doi.org/10.1590/S151969842010000600001. PMid:21225153.

GAMBORG, O.L., MILLER, R. and OJIMA, K., 1968. Nutrient requirements of suspension cultures of soybean root cells. Experimental Cell Research, vol. 50, no. 1, pp. 151-158. http:// dx.doi.org/10.1016/0014-4827(68)90403-5. PMid:5650857.

HARMAN, D., 2002. Aging: a theory based on free radical and radiation chemistry. Science's SAGE KE, vol. 2002, no. 37, pp. 14. http://dx.doi.org/10.1126/sageke.2002.37.cp14. 
HARMAN, D., 2003. The free radical theory of aging. Antioxidants E Redox Signalling, vol. 5, no. 5, pp. 557-561. http://dx.doi. org/10.1089/152308603770310202. PMid:14580310.

ITO, K., COLLEY, T. and MERCADO, N., 2012. Geroprotectors as a novel therapeutic strategy for COPD, an accelerating aging disease. International Journal of Chronic Obstructive Pulmonary Disease, vol. 7, pp. 641-652. http://dx.doi.org/10.2147/COPD. S28250. PMid:23055713.

JANSEN, S.W., AKINTOLA, A.A., ROELFSEMA, F., VAN DER SPOEL, E., COBBAERT, C.M., BALLIEUX, B.E., EGRI, P., KVARTA-PAPP, Z., GEREBEN, B., FEKETE, C., SLAGBOOM, P.E., VAN DER GROND, J., DEMENEIX, B.A., PIJL, H., WESTENDORP, R.G. and VAN HEEMST, D., 2015. Human longevity is characterised by high thyroid stimulating hormone secretion without altered energy metabolism. Scientific Reports, vol. 5, no. 1, pp. 11525. http:// dx.doi.org/10.1038/srep11525. PMid:26089239.

JOMEHZADEH, N., JAVAHERIZADEH, H., AMIN, M., SAKI, M., ALOUQAILI, M.T., HAMIDI, H., SEYEDMAHMOUDI, M. and GORJIAN, Z., 2020. Isolation and identification of potential probiotic Lactobacillus species from feces of infants in southwest Iran. International Journal of Infectious Diseases, vol. 96, pp. 524-530. http://dx.doi.org/10.1016/j.ijid.2020.05.034. PMid:32439543.

KOVAL, L., ZEMSKAYA, N., ALIPER, A., ZHAVORONKOV, A. and MOSKALEV, A., 2021. Evaluation of the geroprotective effects of withaferin A in Drosophila melanogaster. Aging, vol. 13, no. 2, pp. 1817-1841. http://dx.doi.org/10.18632/aging.202572. PMid:33498013.

LASHMANOVA, E.A., KUZIVANOVA, O.A., DYMOVA, O.V. and MOSKALEV, A.A., 2019. The effects of cloudberry fruit extract on Drosophila melanogaster lifespan and stress resistance. Advances in Gerontology, vol. 9, no. 2, pp. 254-260. http:// dx.doi.org/10.1134/S2079057019020127.

LINCHEVA, V., PETKOVA, N. and IVANOV, I., 2017. Optimization of biologically active substances extraction process from Potentilla reptans L. aerial parts. Journal of Applied Pharmaceutical Science, vol. 7, no. 2, pp. 174-179.

LIU, Y., WENG, W., GAO, R. and LIU, Y., 2019. New insights for cellular and molecular mechanisms of aging and aging-related diseases: herbal medicine as potential therapeutic approach. Oxidative Medicine and Cellular Longevity, vol. 2019, pp. 4598167. http:// dx.doi.org/10.1155/2019/4598167. PMid:31915506.

MARTEL, J., CHANG, S.-H., WU, C.-Y., PENG, H.-H., HWANG, T.-L., KO, Y.-F., YOUNG, J.D. and OJCIUS, D.M., 2021. Recent advances in the field of caloric restriction mimetics and anti-aging molecules. Ageing Research Reviews, vol. 66, pp. 101240. http://dx.doi. org/10.1016/j.arr.2020.101240. PMid:33347992.

MILENTYEVA, I.S., SUKHIKH, S.A., YANG, Y., BABICH, O.O., and ZIMINA, Z.I., 2020. Antibiotic activity and resistance of lactic acid bacteria and other antagonistic bacteriocin-producing microorganisms. Foods and Raw Materials, vol. 8, no. 2, pp. 377384. http://dx.doi.org/10.21603/2308-4057-2020-2-377-384.

MOHARRAM, H.A. and YOUSSEF, M.M., 2014. Methods for determining the antioxidant activity: a review. Alexandria Journal of Food Science and Technology, vol. 11, no. 1, pp. 31-42. http://dx.doi.org/10.12816/0025348.

MOSKALEV, A., CHERNYAGINA, E., KUDRYAVTSEVA, A. and SHAPOSHNIKOV, M., 2017. Geroprotectors: a unified concept and screening approaches. Aging and Disease, vol. 8, no. 3, pp. 354363. http://dx.doi.org/10.14336/AD.2016.1022. PMid:28580190.

MURASHIGE, T. and SKOOG, F., 1962. A revised medium for rapid growth and bio assays with tobacco tissue cultures. Physiologia Plantarum, vol. 15, no. 3, pp. 473-497. http://dx.doi. org/10.1111/j.1399-3054.1962.tb08052.x.
MUSCAT, S.M. and BARRIENTOS, R.M., 2020. Lifestyle modifications with anti-neuroinflammatory benefits in the aging population. Experimental Gerontology, vol. 142, pp. 111144. http://dx.doi. org/10.1016/j.exger.2020.111144. PMid:33152515.

NHUT, D.T., HAI, N.T., HUY, N.P., CHIEN, H.X. and NAM, N.B., 2013. New achievement in Panax vietnamensis research. In: S. JAIN and S. D. GUPTA, eds. Biotechnology of neglected and underutilized crops. Dordrecht: Springer. pp. 43-57. http:// dx.doi.org/10.1007/978-94-007-5500-0_3

NOVIKOVA, T., AMBROS, E., ZHELEZNICHENKO, T., ZAYTSEVA, Y. and OYUNBILEG, Y., 2020. Agrobacterium rhizogenes-transformed roots of Astragalus membranaceus (Fisch. Ex Link) Bunge as a source of valuable secondary metabolites. BIO Web of Conferences, vol. 24, pp. 00064. http://dx.doi.org/10.1051/ bioconf/20202400064.

OLENNIKOV, D.N., KASHCHENKO, N.I. and CHIRIKOVA, N.K., 2016. Meadowsweet teas as new functional beverages: comparative analysis of nutrients, phytochemicals and biological effects of four Filipendula species. Molecules, vol. 22, no. 1, pp. 16. http:// dx.doi.org/10.3390/molecules22010016. PMid:28035976.

PIWOWARSKI, J.P., GRANICA, S., ZWIERZYŃSKA, M., STEFAŃSKA, J., SCHOPOHL, P., MELZIG, M.F. and KISS, A.K., 2014. Role of human gut microbiota metabolism in the anti-inflammatory effect of traditionally used ellagitannin-rich plant materials. Journal of Ethnopharmacology, vol. 155, no. 1, pp. 801-809. http://dx.doi. org/10.1016/j.jep.2014.06.032. PMid:24969824.

POLLACK, M. and LEEUWENBURGH, C., 1999. Molecular mechanisms of oxidative stress in aging: free radicals, aging, antioxidants and disease. In: C.K. SEN, L. PACKER and O. HÌNNINEN, eds. Handbook of oxidants and antioxidants in exercise. Amsterdam: Elsevier, chap. 30, pp. 881-926.

PROSHKINA, E., PLYUSNIN, S., BABAK, T., LASHMANOVA, E., MAGANOVA, F., KOVAL, L., PLATONOVA, E., SHAPOSHNIKOV, M. and MOSKALEV, A., 2020. Terpenoids as potential geroprotectors. Antioxidants, vol. 9, no. 6, pp. 529. http://dx.doi.org/10.3390/ antiox9060529. PMid:32560451.

SCHENK, R.U. and HILDEBRANDT, A.C., 1972. Medium and techniques for induction and growth of monocotyledonous and dicotyledonous plant cell cultures. Canadian Journal of Botany, vol. 50, no. 1, pp. 199-204. http://dx.doi.org/10.1139/b72-026.

TRONG, T.T., TRUONG, D.-H., NGUYEN, H.C., TRAN, D.-T., THI, H.-T.N., DANG, G. and HUU, H.N., 2017. Biomass accumulation of Panax vietnamensis in cell suspension cultures varies with addition of plant growth regulators and organic additives. Asian Pacific Journal of Tropical Medicine, vol. 10, no. 9, pp. 907-915. http:// dx.doi.org/10.1016/j.apjtm.2017.08.012. PMid:29080621.

TSAI, Y.-C., CHENG, L.-H., LIU, Y.-W., JENG, O.-J. and LEE, Y.-K., 2021. Gerobiotics: probiotics targeting fundamental aging processes. Bioscience of Microbiota, Food and Health, vol. 40, no. 1, pp. 1-11. PMid:33520563.

TUNDISI, J.G., MATSUMURA-TUNDISI, T. and TUNDISI, J.E.M., 2008. Reservoirs and human well being: new challenges for evaluating impacts and benefits in the neotropics. Brazilian Journal of Biology $=$ Revista Brasileira de Biologia, vol. 68, no. 4, suppl., pp. 1133-1135. http://dx.doi.org/10.1590/S151969842008000500020. PMid:19197483.

VIJENDRA, P.D., JAYANNA, S.G., KUMAR, V., SANNABOMMAJI, T., RAJASHEKAR, J. and GAJULA, H., 2020. Product enhancement of triterpenoid saponins in cell suspension cultures of Leucas aspera Spreng. Industrial Crops and Products, vol. 156, pp. 112857. http://dx.doi.org/10.1016/j.indcrop.2020.112857. 
WAKSMUNDZKA-HAJNOS, M., SHERMA, J. and KOWALSKA, T., 2008. Thin layer chromatography in phytochemistry. Boca Ratón: CRC Press. http://dx.doi.org/10.1201/9781420046786.

YONG, Y., ASYAKINA, L.K., BABICH, O.O., DYSHLYUK, L.S., SUKHIKH, S.A., POPOV, A.D. and KOSTYUSHINA, N.V., 2020. Physicochemical properties and biological activity of extracts of dried biomass of callus and suspension cells and in vitro root cultures. Food Processing: Techniques and Technology, vol. 58, no. 3, pp. 480-492. http://dx.doi.org/10.21603/20749414-2020-3-480-492.

ZHOU, X., SUN, H., TAN, F., YI, R., ZHOU, C., DENG, Y., MU, J. and ZHAO, X., 2021. Anti-aging effect of Lactobacillus plantarum HFY09-fermented soymilk on D-galactose-induced oxidative aging in mice through modulation of the Nrf2 signaling pathway. Journal of Functional Foods, vol. 78, pp. 104386. http://dx.doi. org/10.1016/j.jff.2021.104386. 